\title{
Spatial shifts in migration governance: Public-private alliances in Swedish immigration administration
}

EPC: Politics and Space $0(0) 1-18$ (C) The Author(s) 2021 (c) (1)

Article reuse guidelines: sagepub.com/journals-permissions DOI: 10.1 | 777/2399654421।1043523 journals.sagepub.com/home/epc

\section{Linn Axelsson (D) and Nils Pettersson (D)}

Stockholm University, Sweden

\begin{abstract}
Non-state actors are increasingly involved in enforcing immigration policies. Of late, there has been growing recognition that greater involvement of non-state actors has contributed to reconfiguring migration governance in a spatial sense. Scalar literature conceptualises the involvement of non-state actors as a move by immigration authorities to use actors beyond the state to enforce immigration policies. Network-inspired analysis, on the other hand, draws attention to attempts by non-state actors to form alliances in order to influence immigration policy. In this paper, we set out to show that other spatial shifts are at play in contemporary migration governance. In order to make sense of these spatial shifts, we advance a reading of migration governance which aims to show how efforts to manage migration are the result of, and result in, strategic attempts by state and non-state actors to enrol others, establish a sense of presence and build relationships of proximity and reach. We provide one example of this, involving an administrative alliance between a Swedish government agency and two intermediary actors in labour migration: employers in the information-technology industry and immigration service providers. By drawing attention to spatial shifts in migration governance such as this, new light can be shed on the ways in which the governance of migration recasts relationships between state and nonstate actors.
\end{abstract}

\section{Keywords}

Migration governance, spatial shifts, public-private alliances, scales, networks, proximity, presence

\section{Corresponding author:}

Linn Axelsson, Department of Human Geography, Stockholm University, SE-I06 9I Stockholm, Sweden.

Email: linn.axelsson@humangeo.su.se 


\section{Introduction}

In recent years, there has been growing interest in the role of private actors in international labour migration. A wide range of commercial actors are increasingly involved in the global circulation of differentially skilled labour. These include immigration lawyers (Khan, 2019), recruitment agencies (Kern and Müller-Böker, 2015; Xiang, 2007, 2012; Zhang and Axelsson, 2021), multinational corporations (Ewers, 2007; Millar and Salt, 2007), temporary staffing agencies (Alberti and Danaj, 2017; Coe et al., 2007; Enright and Pemberton, 2016; Hedberg and Olofsson, forthcoming; Knox, 2018), executive search firms (Beaverstock, 2018; Faulconbridge et al., 2009) and a variety of actors delivering cross-cultural training and accommodation, real-estate investment and travel services to the highly skilled (Cranston, 2014; Koh and Wissink, 2018). Of late, there is a recognition that one of the roles of these actors is to engage with immigration policy and practice. Some intermediary actors, for example, strategically avoid immigration regulations (Alberti and Danaj, 2017; Knox, 2018; Yeoh et al., 2017), while others adapt to them (Millar and Salt, 2007) or try to change them (Axelsson and Hedberg, 2018; Betts, 2013; Enright and Pemberton, 2016; Hedberg and Olofsson, forthcoming; Khan, 2019). Nevertheless, their role in the governance of international migration remains underexplored.

The growing involvement of a host of private actors in migration governance is the focus of a different literature, which argues that responsibilities for immigration control have been transferred upwards to the supra-national scale (e.g. Betts, 2011), downwards to local state actors (e.g. Cohen, 2002) and outwards to private actors (e.g. Scholten, 2015). Detention and deportation, for example, are widely contracted out to private security companies (Doty and Wheatley, 2013; Flynn and Cannon, 2009; Hiemstra and Conlon, 2017; Martin, 2012), and controls of immigration status are increasingly performed by a variety of private actors who include transportation companies and employers for example (de Lange, 2011; Lahav, 1998; Scholten, 2015; Yuval-Davis et al., 2018). By outsourcing immigration control to private actors, this literature argues, states are placing some of the burden of immigration policy enforcement outside the state.

In both sets of literature, there is a tendency to cast states and private actors as separate entities. Conventional accounts of intermediary actors in international labour migration, as Xiang Biao (2012) has noted, place private actors between states and migrants. From this inbetween position they sometimes influence immigration policy and practice directly, for example by engaging in dialogue with state actors (Hedberg and Olofsson, forthcoming), or contesting decisions by immigration authorities or the immigration system at large (Khan, 2019). Their influence can equally be indirect, for example when the exploitative practices of certain intermediary actors prompt stricter regulations (Axelsson et al., 2021). Similarly, scalar readings of migration governance tend to emphasise how certain responsibilities for immigration control have been placed on actors beyond the state. In this view, externalisation serves to distance states from immigration policy enforcement, in particular its less agreeable manifestations such as detention and deportation. However, the relationship between public and private actors is not necessarily as binary as previous research suggests. Some intermediary actors, as Xiang (2012) has argued, actually emerge from inside state bureaucracy, as in the case of China, where most licensed recruitment agencies are state-owned, formerly state-owned or run by former state officials. We argue that a spatially sensitive analysis is needed of how this contributes to reconfiguring the relationships between public and private actors, in order to move forward the debate about the growing involvement of non-state actors in migration governance. Indeed, in a spatial sense, the increasing involvement of private actors in immigration control is just as much the result 
of a spatial shift in migration governance that has arguably received less attention. This shift involves strategic attempts by public and private actors to enrol others, establish a sense of presence and build relationships of proximity and reach in an effort to shape migration from within, rather than from an external position as most previous research suggests (see e.g. Goh et al., 2017; Khan, 2019; Lahav, 1998; Statham and Geddes, 2006).

In order to trace this spatial shift, the paper examines work permit administration, a central component of the regulation of international labour migration. Work permit systems regulate the movement of labour migrants across borders, as well as their access to labour markets and other rights in many countries (see e.g. Koslowski, 2014). Consequently, a significant number of public administrators around the globe are involved in translating these systems into actions and in delivering managed labour migration to the public. In order to make decisions about who is allowed to enter a country and access its labour market, administrators need documents which confirm identity, prove educational background and previous work experience, and clarify terms of employment. Processing these documents takes time, and public authorities are constantly developing new operational strategies to streamline administration and cut processing times. This paper focuses on the enrolment of two types of intermediary actor in work permit administration in Sweden employers and immigration service providers. In particular, it draws attention to the strategic interactions between these actors and the Migration Agency ( $s w$. Migrationsverket), the government agency responsible for implementing Swedish immigration law, as they attempt to build relationships to streamline work permit administration and reduce processing times.

The paper draws on several years' research on Swedish work permit administration. Its main focus is how an administrative alliance between public and private actors - a nationwide fast-track for work permit applications ( $\mathrm{sw}$. certifieringssystemet) - was formed in the late 2000s and early 2010s, and the continued attempts by public and private actors to speed up work permit administration by building relationships of proximity and reach. Documentary analysis and semi-structured interviews were conducted with representatives of the Migration Agency in order to analyse the role of state actors in the fast-track. The documentary analysis covers the period 2008-2018. It includes ministry directives ( $s w$. regleringsbrev avseende Migrationsverket), the Migration Agency's annual reports, and its guidance for staff making decisions on applications, known as the migration handbook ( $s w$. handbok i migrationsärenden), which outlines the Agency's interpretation of immigration law. The documentary analysis also includes administrative directives and other internal documents relating directly to the formation and development of the fasttrack. In addition, we interviewed 11 staff at the Agency's work permit units. The sample was purposefully constructed to include caseworkers, team leaders and heads of work permit units. In order to analyse the role of non-state actors in the fast-track, and in work permit administration more broadly, we conducted 31 semi-structured interviews with two types of intermediary actor: employers in the information-technology (IT) industry and immigration service providers. The latter included relocation companies, global accountancy firms and immigration lawyers. The decision to focus the sample on the IT industry was based on the fact that actors in this industry were directly involved in the establishment of the fast-track. Additionally, while this process is not designed specifically for IT firms but for all firms which sponsor large volumes of applicants each year, IT firms tend to dominate the fast-track simply because IT professionals represent the main flow of skilled labour to the Swedish labour market. ${ }^{1}$ Respondents were purposefully sampled on the basis of information from the Migration Agency about those involved in the fast-track. We also selected a number of large-scale, medium-sized and small-scale employers and immigration service 
providers from a list of all firms that applied for work permits for IT professionals. In addition, we conducted six interviews with representatives of business organisations and trade unions which were involved in the establishment of the fast-track. Both documents and interview transcripts were coded and analysed through an iterative process (Nowell et al., 2017), using both predetermined and emerging categories of analysis.

In the following section, we explore what engagement to date there has been with spatial aspects of governance in migration studies. Specifically, we focus on how scalar and network-inspired analysis understand the growing involvement of non-state actors in the regulation of international migration. We then attempt to show how the enrolment of private actors in migration governance is more than a state strategy to extend immigration control into the private realm; it is also about attempts by state and non-state actors to draw others within close reach in order to influence migration. Drawing on the example of work permit administration, we trace the strategies and interactions of public and private actors as they bridge interests, form an administrative alliance which enrols private actors in migration governance, and negotiate processing times by building relations of proximity and presence. In the final part, we try to establish what this particular reading of the relationship between public and private actors can contribute to the understanding of the spatialities of migration governance.

\section{Spatial shifts in migration governance}

The growing sense that border and immigration control are no longer monopolised by governments has, to some extent, fuelled spatial speculation about the relationship between state and non-state actors in the governance of migration. This analysis conceptualises contemporary trends in migration governance as a rescaling of core functions of immigration enforcement upwards, downwards and outwards to actors beyond the state, a move which enables states to govern migration at a distance. Scalar readings, however, do not account for all spatial shifts in the governance of international migration. By placing nonstate actors at the centre, rather than the state, network-inspired analysis has revealed that non-state actors are also involved in shaping immigration policy. Their attempts at exerting an influence are often about intensifying interactions with influential state actors or building close-knit alliances with other interest groups and organisations. The governance of migration through networks also reshapes relationships between public and private actors in a spatial sense, albeit in a different way to what the scalar literature suggests. Arguably less attention has been given to how both state and non-state actors seek to dissolve distance and enrol others in migration governance.

\section{Rescaling migration governance}

It is a generally held view that states monopolise the power to decide who is allowed to circulate within and across their borders. However, just as state power in general has been decentred, diffused and fragmented as a consequence of neoliberal economic restructuring (see e.g. Brenner, 1999; Jessop, 1994; Rhodes, 1994), so too has control over immigration. In migration studies, there has been considerable interest in the upward shifting of responsibilities for immigration control to the supra-national scale, and to entities such as the European Union (e.g. Betts, 2011; Kunz et al., 2011; Lahav, 1998; Lavenex, 2006; Leitner, 1997; Panizzon and van Riemsdijk, 2019). There is now a proliferation of instruments which aim to harmonise and/or restrict immigration in Europe, including the Amsterdam Treaty, the Dublin Convention (Lahav, 1998), the EU Blue Card Directive 
(van Riemsdijk, 2012) and FRONTEX, the EU's agency for border security (Carrera, 2007). Control of immigration status has also been transferred downwards to the local scale (Lahav, 1998), where schools, hospitals and welfare offices, for example, are charged with the responsibility of monitoring immigration status and regulating access to education and welfare services (Bendixsen, 2018; Cohen, 2002; Schweitzer, 2017).

The scalar literature on migration governance also argues that state responsibilities have been transferred outwards to non-state actors. Detention and deportation, for example, are widely contracted out to private actors (e.g. Darling, 2016; Doty and Wheatley, 2013; Flynn and Cannon, 2009; Hiemstra and Conlon, 2017; Martin, 2012), as is the processing of visa applications (Infantino, 2016; Sánchez-Barrueco, 2018). Responsibilities for control of migration status have also been divested to a variety of non-state actors, including carrier companies (Lahav, 1998; Scholten, 2015), employers (de Lange, 2011; Lahav, 1998; YuvalDavis et al., 2018), banks, landlords (Yuval-Davis et al., 2018) and universities (Jenkins, 2014). Governments have long been coercing transportation companies into performing immigration control on behalf of the state. In the early twentieth century, ships carrying migrants to the United States were required to provide immigration authorities with information about their passengers (Zolberg, 2003). Employer sanctions, which place the responsibility for checking workers' identities and migration status on employers, have an equally long history. In France, for example, employer sanctions were first introduced in 1926 (Lahav, 1998). Since then, employer sanctions have been rolled out in a range of countries (e.g. de Lange, 2011; Scholten, 2015; Yuval-Davis et al., 2018), where governments use the threat of sanction to coerce employers into taking part in immigration policy enforcement, by performing identity checks in workplaces for example.

Running through most scalar accounts of migration governance is a tendency to interpret these trends as an externalisation of immigration control, which enables states to govern migration at a distance or, as Aristide Zolberg (2003) has argued, remotely. By transferring liabilities to private actors, governments are not just seeking to improve efficacy and to transfer to the private sector some of the costs of enforcing immigration policies. Outsourcing also enables governments to distance themselves from accountability and some of the more 'unpleasant' forms of immigration control such as detention and deportation. The outward move of immigration control, in this view, is consequently not so much about a retreat or hollowing out of the state (see e.g. Rhodes, 1994) in matters of immigration, as about introducing additional layers of immigration control between states and migrants (Guiraudon and Lahav, 2000; Lahav, 1998; Menz, 2013).

Scalar readings of migration governance consequently tend to portray the outward transfer of core functions of immigration policy enforcement to actors beyond the state as the result of deliberate state strategies. However, the growing involvement of intermediary actors in the governance of international migration, we argue, is not just a state strategy for improving efficiency or inserting distance. It is equally the result of attempts by non-state actors to position themselves in relation to the state in order to influence immigration, as discussed in research which draws its inspiration from network analysis.

\section{Governing migration through networks}

Any reference to the influence of non-state actors on the regulation of immigration invariably draws attention to Gary Freeman's (1995) classic text which emphasised the need to examine the interaction between public officials and interest groups in order to understand immigration politics in liberal democratic states. According to Freeman, pro-immigration interest groups, such as business organisations and employers, have often tended to be better 
organised than those wishing to limit migration. As a consequence, they have been more successful at developing close relationships with state officials and at persuading governments to adopt liberal immigration policies.

More recent attempts to explore the influence of non-state actors on immigration policy draw inspiration from different types of network analysis. Paul Statham and Andrew Geddes (2006), for example, use insights from quantitative network analysis to calculate the centrality of state and non-state actors in relation to others. According to their analysis, non-state actors cluster around a shared opposition to state policy, and lobby for change. However, they generally fail to pressurise the state into adopting a more generous asylum policy. Will Somerville and Sara Wallace Goodman (2010), by contrast, opt to categorise constellations of state and non-state actors that exist in three areas of migration governance: asylum policy, labour migration and integration policy, as either loosely associated or closeknit. In this analysis, which draws on policy network literature, non-state actors who are able to forge connections with state actors tend to be more successful at influencing immigration policies. Accordingly, close-knit associations between state and non-state actors in the area of labour migration were instrumental in the development of labour migration policies in the UK, while more loosely organised interests in the areas of asylum and integration were unable to reach similar levels of influence.

By focusing on the density of relations in quantitative terms, or relational closeness between state and non-state actors, network-inspired analysis has contributed to a different understanding of the growing involvement of non-state actors in the governance of international migration. This understanding places organisations and interest groups firmly among actors who more or less successfully exert an influence on immigration policies. Importantly, if Statham and Geddes' analysis positions civil society in opposition to and outside the state, in an external position from which they try to assert power over asylum policy, Somerville and Goodman's analysis suggests that non-state actors' ability to exert an influence also lies in the capacity to forge connections and work with influential state actors to change labour immigration policies. However, these accounts involve a lingering sense of distance between state and non-state actors, a lack of recognition that these two sets of actors often depend on each other to fulfil their aspirations, and may therefore act jointly to reach their goals (see e.g. Emerson et al., 2012; Klijn, 1996). In order to appreciate the relationship between state and non-state actors in migration governance more fully, there may consequently be a need to move the debate about migration governance beyond scales or networks.

\section{Migration governance beyond scales or networks}

To overcome the sense of distance between state and non-state actors in scalar and networked readings of the growing involvement of private actors in migration governance, in this paper, we draw inspiration from John Allen's (e.g. 2003, 2009, 2016) conceptualisation of power. Power, Allen argues, is neither scalar nor networked, but a relational effect of exchanges and interactions between state and non-state actors. This view suggests that the power to influence immigration is not something that can simply be extended outwards by divesting responsibilities to private actors. Nor is it something that empowers particular groups to exert an influence over immigration policies from an external position. Instead, power is the outcome of certain spatial practices which enable state and non-state actors to make their leverage felt. The intention behind such spatially mediated practices may indeed be to place specific issues beyond reach or, in the language used above, to insert distance between the state and immigration control. However, they may equally be about drawing 
others close through a sequence of enrolling strategies. The kind of power which interests us in this paper is consequently one which is deeply spatial in nature, and relies on the capacity of interdependent state and non-state actors to position themselves close to, and work with others to shape migration. The capacity to draw others close, to forge alliances, in turn, tends to rely on quieter forms of power (Allen, 2003). State actors, for example, may not be able to rely simply on coercion or the threat of sanction to enrol non-state actors, as discussed earlier, but may also have to draw on combinations of incentive and dialogue to entice non-state actors into taking part in immigration policy enforcement. Non-state actors, in turn, may seek to persuade state actors to perform in particular ways or engage in negotiation or bargaining to achieve certain goals. Equally, in certain instances, the best way to make leverage felt is to form alliances and act jointly to regulate migration.

Possibly less understood is how these kinds of enrolling strategies could also involve the formation of shared spaces which enable both state and non-state actors to exert an influence over migration from within, rather than from an external position, as scalar and networked accounts seem to suggest. As non-state actors become integral to migration governance, continuous and constructive public-private interaction can deepen relationships further, and open up new spaces for communication and collaboration.

If indeed migration governance currently relies on the ability of state and non-state actors to bridge interests, form mutual understandings and act jointly, the challenge is surely to broaden the scope beyond scales or networks. To do so requires detailed exploration of another spatial shift in migration governance which is the result of, and results in, the formation of relationships of proximity and presence between state and non-state actors, rather than distance.

\section{Proximity and presence in Swedish immigration administration}

As part of this challenge, we turn the attention to a key process through which labour migration is governed: work permit administration, and the ways in which public and private actors strategically build relations of proximity and presence as they try to reduce the time it takes to process applications.

The Swedish work permit system was significantly altered in December 2008, when the parliament voted in favour of opening up the labour market to foreign workers of all skill levels. The amendment of Swedish immigration law resulted in new roles for some of the actors involved in work permit administration in Sweden. The labour market boards, whose assessment of work permit applications relied heavily on the expertise of trade unions, were phased out. Instead, trade unions were given the right to comment on the terms of employment, a potential route to influence which many trade unions have opted not to use (OECD, 2011). In consequence, it often falls on the Migration Agency to assess the terms of employment offered by employers who wish to recruit foreign labour.

This section focuses on how a fast-track for work permit applications was developed. We begin by positioning the fast-track within a long-term debate about the impact of long processing times for work permit applications on Sweden's business community, in particular the IT industry. We then consider the enrolling strategies of the Migration Agency and two sets of intermediary actors: employers in IT and immigration service providers, in terms of how they jointly forged an administrative alliance to reduce processing times. We show how the fast-track has drawn employers and immigration service providers into the regulation of international migration in Sweden, and how this, in turn, has altered the relationship between public and private actors in a spatial sense. Finally, we explore how the fasttrack also contributed to establishing a shared space within and beyond which employers, 
immigration service providers and the Migration Agency strategically continue to negotiate processing times. A focus on relationships of proximity and presence, rather than distance, we claim, opens up a different way of conceptualising the role of private actors in migration governance.

\section{The problem of processing times}

Quick access to international expertise is often described as crucial to the IT industry. For multinationals, which by definition operate in several countries simultaneously and therefore need to send managers and staff between branches at speed, slow immigration processes have consequences. Other firms, including start-ups, require quick access to international expertise in order to grow their businesses. IT firms consequently tend to describe the slowness of immigration administration as a genuine obstacle to their operations (Axelsson, 2018; Millar and Salt, 2007; Nathan and Vandore, 2014). Public actors see speed as equally central. Delays and backlogs are frequently identified as key problems of immigration administration and quick decision-making is generally portrayed as the mark of a successful immigration system, as Saulo Cwerner (2004) has argued for example.

Similarly, in Sweden, the time it takes the Migration Agency to process work permit applications has been constructed as a problem of government by both private and public actors. Processing times were steadily on the rise until, in 2017, the average processing time for a work permit application reached 197 working days (Swedish Migration Agency, 2019). Employers in IT have long expressed concerns about having to wait for decisions on work permit applications, claiming that waiting for work permits for extended periods impedes their ability to recruit expertise in a highly competitive global labour market characterised by a shortage of IT professionals (Axelsson, 2018). One employer explained how embarrassing they found it when they had to inform an international IT expert that:

You will have to wait six months before you have your permit ... maybe, we do not know [how long it will take], and they [the Migration Agency] will not give us any information about when it might be granted, so you will just have to live your life and wait. [The interviewee continued]: No one wants to move overseas on those terms. (Employer 12)

Consequently, for decades, employers in IT have strategically sought to draw state actors' attention to the problem of processing times. For example, some employers have joined forces and posted information on social media about the impact of long processing times on the industry. Others have turned to the news media, at times in collaboration with business organisations, to draw attention to specific cases they think illustrate how the work permit system is failing, and how processing times must be shortened. In other instances, employers in IT have moved up the political ladder to attract the attention of the Migration Agency through ministerial intervention. For example, in a letter to the Minister of Justice, a main provider of IT services in Sweden argued that long and unpredictable processing times hampered the company's ability to deliver IT services to its customers and, consequently, to compete for contracts. In the letter, the employer requested a meeting with the Minister, arguing that long processing times were putting such a strain on business that it needed to be dealt with at the highest level of government. Private actors also rely on dialogue to establish a mutual public-private understanding about the problem of processing times. More experienced employers and immigration service providers claim that, over time, they have established channels of communication which they can use to bridge interests, draw the Migration Agency into their reality, and persuade it that shorter processing times are 
necessary. One employer, for example, explained how, after cultivating contacts with Migration Agency staff, he called and visited the Agency's offices on several occasions to discuss the problem of processing times, in particular the damage that long and unpredictable processing times represent for Sweden's business community.

Like private actors, the Swedish state has adopted this "discourse about, and desire for, speed" (Cwerner, 2004: 72). This is articulated, for example, in Parliamentary Ombudsman (e.g. 2014) and National Audit Office (Swedish National Audit Office, 2016) reports, and in government directives from the Ministry of Justice, the government body responsible for the area of immigration. In these directives, the Ministry repeatedly instructs the Migration Agency to introduce measures to shorten processing times (e.g. Ministry of Justice, 2007, 2009, 2016). Several of the interviews with Migration Agency staff confirmed that the Agency accepts that processing times are very long, even "grotesque" as one interviewee put it (Swedish Migration Agency 1). They agreed that the system for processing work permits has to speed up if the industry's need for access to international labour is to be met.

In other words, corporate players in the IT industry and main state institutions in the area of immigration regulation would appear to claim a shared interest in reducing processing times for work permit applications. In consequence, there is scope to bridge interests and forge alliances, as discussed in the next section.

\section{A public-private alliance to fast-track work permit applications}

In the late 2000s, work permit unit three of the Migration Agency's Stockholm office began work on streamlining administration and speeding up decision-making. As a result, between October 2011 and October 2012, the Agency trialled a new administrative arrangement, a fast-track to speed up the work permit application process. This version of the fast-track, which was the Migration Agency's second attempt at speeding up work permit administration by enrolling non-state actors, sought to draw a few key multinationals, predominantly in IT, into work permit administration. It also invited a number of immigration service providers, who specialised in preparing work permit applications on behalf of their corporate clients, to share some of the administrative burden of the work permit system. In this way, firms that did not meet the requirements of membership, which included applying for at least 50 work permits per year during the trial period, could access the fast-track by purchasing the services of these actors (Axelsson, 2017; Swedish Migration Agency, 2011).

After a successful trial, during which fast-tracked applications were decided within two to five days, the fast-track was made permanent. At the same time, the required number of applications was reduced to 25 per year (Swedish Migration Agency, 2012). Since then, the requirement to apply for a certain number of work permits per year has been dropped. No changes were required to immigration law in order to establish the fast-track. Instead, this arrangement was the result of discretionary decisions by civil servants to enter into an administrative alliance with selected private actors with whom they shared a commitment to resolve the problem of processing times (ibid.). It was equally the result of a decision by private actors to enter into an alliance with state actors, because they too had something to gain by becoming involved in immigration administration. As such, proximity is built into this arrangement, both in the formation of a mutual public-private understanding about problems and solutions, and in the enrolment of private actors to perform tasks which ultimately are related to granting access to Swedish territory and the Swedish labour market.

The first administrative role that members of the fast-track perform, which would otherwise fall on the Migration Agency, is to check that the application has been filled in correctly, and that all documents required by the Agency to process it are attached. 
This includes, for example, copies of the employee's passport, diplomas and certificates, and the employment contract. The second role involves checking that applications abide by immigration law. This includes providing evidence that the position has been advertised in Sweden, the European Economic Area and Switzerland for at least ten days, to show compliance with the European Union's Generalised System of Preferences. It also includes evidence that the terms of employment align with those set out in collective agreements or, in the absence of a collective agreement, prevailing practice within the occupation or sector, as well as proof that trade unions have been given an opportunity to vet the employment contract. Moreover, if the job is part-time, evidence must be provided that the salary meets a minimum threshold. Different requirements also need to be met for different business types and sectors (Swedish Migration Agency, 2018 b). In order to perform this role, employers and immigration service providers must remain up to date with any changes to the law and its implementation. Immigration service providers also have to vet employers before taking them on as clients, to make sure that only employers who meet the requirements of immigration law are given access to the fast-track.

By taking on these administrative responsibilities, employers and immigration service providers save the Migration Agency considerable time which the Agency can then spend on more complicated cases. This cuts average processing time and enables the Agency to work towards its target of a speedy labour immigration process. One immigration service provider described its role in work permit administration as follows:

It takes us many hours to put together a correct application that includes everything they [the Migration Agency] need to make a quick decision. And all that [work] they [the Migration Agency] do not have to do. We save them [the Migration Agency] an insane amount of time. (Immigration service provider 4)

At the same time, the fast-track saves employers 'an insane amount of time'. Indeed, in exchange for performing these administrative roles, the Migration Agency pledges to give priority to applications from members of the fast-track, and to deliver a decision within ten working days if the application includes a trade-union statement or within 60 working days if not (Swedish Migration Agency, 2018 b). According to the Migration Agency, around 70 per cent of applications for a first work permit are decided within ten working days in the fast-track (Swedish Migration Agency, 2019). There is consequently a strong incentive for both employers and immigration service providers to comply with the requirements of the fast-track, especially since members who fail to live up to their obligations can be excluded from it without the right to appeal (Swedish Migration Agency, 2018a, 2018 b). In other words, in addition to incentive and the promise of an administrative alliance, which can influence the time it takes to access foreign labour, to enrol private actors in work permit administration, the fast-track also relies on the threat of sanction, that is, exclusion from the fast-track, to secure particular forms of conduct. Several of the interviewees spoke about the different strategies they relied on for regulating their behaviour in order to avoid sanctions and, in the case of immigration service providers, strategies for regulating the conduct of their corporate clients. Much of this self-regulation revolved around ensuring that applications were correct when submitted, by checking and double-checking information, both in terms of what they entered into the application system and in terms of keeping up to date with any regulatory changes.

This said, the fast-track is not simply a state strategy aimed at enrolling private actors in work permit administration. By engaging in dialogue with the Migration Agency, some employers and immigration service providers have been closely involved in establishing 
the fast-track itself. In part, dialogue was initiated by intermediary actors, who repeatedly approached the Migration Agency to discuss the problem of processing times and the different ways in which their expertise in processing work permit applications could contribute to a solution. One respondent, for example, explained that immigration service providers not only performed these important administrative roles which were central to a speedy labour immigration process, such as checking that the right documents were attached to each application, they also contributed to work permit administration by excluding employers who had no intention of abiding by immigration law. At the same time, the Migration Agency has sought to reach out to private actors and involve them in its work to streamline administration and reduce processing times. For example, before launching the fast-track, the Agency organised a workshop to discuss different ways of fast-tracking work permit applications. It also involved private actors in the development of an online application system, and invited non-state actors to pilot different types of fast-track. Dialogue and consultation made it increasingly clear that private actors had an interest in working closely with the Agency to speed up decision-making. Continuous conversation between the Agency, employers and immigration service providers ultimately indicated that an administrative alliance could provide a solution to the problem of processing times. In other words, the Migration Agency staff suggested that, while the Agency may have decided that it was in its interest to use its discretionary power to establish a fast-track, the fasttrack was just as much the result of a joint public-private understanding that both sides had something to offer in terms of a solution to the shared problem of processing times.

In a spatial sense, the fast-track has consequently produced a shift in the relationship between state actors and intermediaries. By joining forces with the Migration Agency to form an alliance, and by taking on several key administrative responsibilities, employers and immigration service providers have become integral to work permit administration in Sweden. However, their involvement in this aspect of the implementation of immigration policies is not, as previous research might lead us to believe, simply about state attempts to transfer responsibilities to private actors while retaining the power over immigration. Instead, the growing involvement of private actors in work permit administration is just as much about a series of enrolling strategies by state and non-state actors, which serve to dissolve the distance between them. Moreover, the way we see it, the power to influence labour migration, to speed it up or slow it down, is in part a relational effect of this publicprivate arrangement. As such, intermediary actors are not just drawn into an alliance with state actors; they are actively involved in shaping it. Equally, they do not simply take on administrative responsibilities associated with the work permit system; they also exercise power through these responsibilities. Indeed, in the ability to fill in an application so that it generates a quick, positive decision, lies an indirect power to influence who is granted access to the Swedish labour market. However, the alliance between public and private actors does not mean that work permit administration is friction-free. Instead, the public and private actors continue their efforts to influence processing times both within and beyond the fasttrack. In the next section, we show how this contributes to establishing relationships of proximity and presence between state and non-state actors.

\section{Negotiating time within and beyond the fast-track}

In the previous section, the focus was public and private actors' joint efforts to form an administrative alliance and how those enrolling strategies, in turn, altered the relationships between public and private actors. In this section, we shift the focus to how the fast-track has contributed to the development of shared spaces which enable state and non-state actors 
to continue to form relationships of proximity and presence, and influence work permit administration from within rather than, as previous research suggests, from an external position. Many of the close relationships intermediary actors rely on to influence migration have been built slowly over time, through continuous interaction with the same caseworker or manager. One respondent explained that he had compiled a list of Migration Agency staff with whom he felt he had established a particularly good rapport. By doing so, he had developed a quick, friction-free way of contacting the Agency when he needed to. Other actors use the close relationship developed through continuous interaction with Migration Agency staff to negotiate a position in the fast-track in the first place. For example, one immigration service provider was accepted as a member of the fast-track after explicitly telling Migration Agency staff that the Agency itself would benefit by enrolling an intermediary in the fast-track who produced high-quality applications.

Other actors self-regulate to establish a sense of presence, and to position themselves close to the Migration Agency. Self-regulation is consequently not only the result of the threat of sanction, as discussed in the previous section, but also an active way for intermediary actors to establish relationships of proximity. In order to achieve this, some private actors invite other employers, immigration service providers and Migration Agency staff to exchange views about how the application process could be improved. This way, they create another space where close relationships between state institutions and private actors can develop. Others request individual meetings with the Migration Agency to discuss and explain elements of employment contracts, or to ask for feedback on applications so that they can improve their success rate. They also instruct applicants carefully about what to include in the application in order to fulfil the requirements, and they sometimes recommend that applicants attach information which is not formally required, so as to improve their chances of receiving a positive decision quickly. If they are not certain an application will be granted, immigration service providers sometimes choose to submit applications through the 'normal' work permit channel to avoid the risk of exclusion from the fasttrack. Moreover, despite the fact that the Swedish IT industry rarely regulates industrial relations through collective agreements, some employers have opted to enter into collective agreements with trade unions in order to meet certain requirements of Swedish immigration law, and to ensure that their applications are placed in the category of applications which the Migration Agency will process quickly.

Attempts by employers and immigration service providers to influence processing times also include efforts to speed up individual cases. These efforts, which often begin soon after an application has been submitted, are designed to make their presence felt. For example, several of the interviewees described how they would repeatedly call the Migration Agency's customer service to ask if their application had been assigned to a caseworker. While this strategy rarely led anywhere, it gave the interviewees a sense that they were trying to do something to speed up the process. Once a caseworker had been assigned, the interviewees used their position in the fast-track to continue to try and establish a sense of presence, and to persuade the Agency to make a decision on their application. As one of the interviewees put it: "Once we got hold of a caseworker who was stupid enough, if I might say so, to answer their phone, we did not stop until they had gone to collect our file and promised to [make a decision on the application]" (Immigration service provider 3). Interviewees also mobilise their experience of, and expertise in the work permit process to influence processing times from within the fast-track system. For example, if a caseworker requests further information, which may result in the application being pulled from the fast-track process, the interviewees bring the caseworker's attention to previous cases where a permit has been granted on similar grounds. Others submit the missing information as quickly as they can, 
then immediately call the caseworker in the hope that they will be able to persuade her or him to keep the application in the fast-track process. In these situations, interviewees often bring together several cases and try to negotiate them at the same time, in order to take advantage of the fact that they have managed to attract a caseworker's attention.

When a decision takes longer than anticipated, or an application is rejected on grounds that the interviewees do not accept, they adopt different strategies to establish a sense of presence. These include contacting the manager of the work permit unit which is processing or deciding their application, in order to complain about a particular caseworker. Other interviewees use their membership of the fast-track to exert pressure on the Migration Agency to process an application quickly. One interviewee said:

You can emphasise that the processing times of the fast-track, they need to be kept. Those outside the fast-track cannot do that, and for them the processing times are not fixed. So that way we [as members of the fast-track] can exert an influence. (Immigration service provider 7)

As noted by the interviewee, not all private actors are equally able to attract the Migration Agency's attention. For example, those excluded from the fast-track cannot draw on membership to exert pressure on the Agency to process their cases within a certain timeframe. Equally, the ability to establish a sense of presence is not evenly distributed among the members of the fast-track. While some believe that they have very little, if any, influence on processing times, employers who supply Sweden with considerable numbers of IT professionals each year make use of their greater presence and visibility to establish themselves as influential negotiators of processing times.

The Migration Agency has also used the fast-track to continue to build relationships of proximity. Thus, in addition to using incentive and the promise of an administrative alliance to enrol private actors in the implementation of labour immigration policies, as discussed in the previous section, the Agency has established a department designated to the fast-track, as well as a contact point members can call or email when they have questions or face problems. Additionally, the Director General has created a reference group for obtaining input from various actors on work permit administration, and on occasion the Agency sends out questionnaires to collect members' points of view and deepen its knowledge about potential routes for further streamlining of work permit administration. The Agency also regularly invites members to meetings where they can share knowledge and provide feedback about which aspects of the fast-track work well, as well as those where improvement is needed. In this way, public and private actors jointly contribute to improving work permit administration while, at the same time, building relationships. A Migration Agency staff member explained that public-private communication is central to the fast-track process: "They listen to us and we listen to them, and we learn from each other. That is the route we have chosen" (Swedish Migration Agency 9).

\section{Conclusion}

At first glance, outsourcing of functions of immigration control may appear simply to be extending some of the burden of immigration policy enforcement beyond the state, a move which serves to insert distance between the state and some of the more 'unpleasant' forms of immigration control. To some extent, networked accounts, which shift the attention from the state to non-state actors, provide a different narrative about the role of non-state actors in migration governance. Instead of suggesting that the growing involvement of non-state actors is the result of state strategies to govern migration at a distance, network-inspired 
analysis shows that non-state actors choose to engage with the state in an attempt to influence it to changing its immigration policies. Whether they succeed depends on their ability to establish some degree of closeness to state actors. However, scalar and networked views of contemporary migration governance, we show in this paper, may serve to obscure other spatial shifts in the governance of international migration that have resulted in, and are shaped through, the growing involvement of private actors in immigration policy enforcement. One of the aims of this paper has consequently been to offer a different way of making sense of the spatial entanglements between state and non-state actors in migration governance, by focusing on the relationships of proximity and presence built by state and nonstate actors when they bridge interests and form alliances to shape migration jointly. Some non-state actors, we have demonstrated in this paper, have currently become an integral part of migration governance as a result of attempts by interdependent public and private actors to strategically draw others in, to dissolve distance, in an attempt to manage labour migration more efficiently.

A further aim of the paper has been to show that the role of private actors in the regulation of international migration is not simply to navigate borders and immigration controls on behalf of their clients, as much previous research on intermediary actors in labour migration has argued. Instead, as private actors become integral to migration governance, continuous and constructive public-private interaction can deepen relationships further and open up new spaces of communication and collaboration. These spaces enable state and non-state actors to shape migration from within, rather than, as most previous research suggests, from an external position.

As such, this paper offers an opportunity to rethink how the growing involvement of private actors in migration governance has reconfigured relationships between state and non-state actors in a spatial sense. Indeed, perhaps somewhat contradictory, we propose that outsourcing the enforcement of immigration policies could be understood as a practice that not only places some of the responsibility for immigration control on entities such as airlines, employers and private security companies. It also enrols these very actors in migration governance. The challenge is now to explore what this re-conceptualisation of the growing involvement of private actors as spatial practices of enrolment means for understanding migration governance more broadly, and whether other spatial shifts in the relationship between state and non-state actors are currently at work in the governance of international migration.

\section{Acknowledgements}

The authors would like to thank the research participants for generously sharing their experiences and Qian Zhang, Stockholm University, and Charlotta Hedberg and Irma Olofsson, Umeå University, for comments on an earlier draft.

\section{Declaration of conflicting interests}

The author(s) declared no potential conflicts of interest with respect to the research, authorship, and/ or publication of this article.

\section{Funding}

The author(s) disclosed receipt of the following financial support for the research, authorship, and/or publication of this article: This work was supported by the Swedish Research Council [grant number 2017-01010]. The authors would also like to acknowledge that funding to cover costs for transcription of interviews was received from Helge Ax:son Johnson's foundation. 


\section{ORCID iDs}

Linn Axelsson (D) https://orcid.org/0000-0002-0969-1333

Nils Pettersson (D) https://orcid.org/0000-0001-7990-1183

\section{Note}

1. In addition to the fast-track, which is the focus of this paper, the Migration Agency also prioritises applications from wild-berry pickers, as they need a work permit at the right time due to the seasonality of their work. Wild-berry pickers and IT professionals are the two main flows of non-European Economic Area labour to Sweden.

\section{References}

Alberti G and Danaj S (2017) Posting and agency work in British construction and hospitality: The role of regulation in differentiating the experiences of migrants. The International Journal of Human Resource Management 28(21): 3065-3088.

Allen J (2003) Lost Geographies of Power. Malden: Blackwell.

Allen J (2009) Three spaces of power: Territory, networks, plus a topological twist in the tale of domination and authority. Journal of Power 2(2): 197-212.

Allen J (2016) Topologies of Power: Beyond Territory and Networks. Abingdon: Routledge.

Axelsson L (2017) Living within temporally thick borders: IT professionals' experiences of Swedish immigration policy and practice. Journal of Ethnic and Migration Studies 43(6): 974-990.

Axelsson L (2018) Om väntan: IT-företags och dataspecialisters erfarenheter av svensk migrationspolitik och praktik. In: Povrzanovic Frykman M and Öhlander M (eds) Högutbildade Migranter i Sverige. Lund: Arkiv förlag \& tidskrift, pp. 71-85.

Axelsson L and Hedberg C (2018) Emerging topologies of transnational employment: 'Posting' Thai workers in Sweden's wild berry industry beyond regulatory reach. Geoforum 89: 1-10.

Axelsson L, Hedberg C, Pettersson N, et al. (2021) Re-visiting the 'black box' of migration: State-intermediary co-production of regulatory spaces of labour migration. Under review.

Beaverstock J (2018) New insights in reproducing transnational corporate elites: The labour market intermediation of executive search in the pursuit of global talent in Singapore. Global Networks 18(3): 500-522.

Bendixsen S (2018) The politicised biology of irregular migrants: Micropractices of control, tactics of everyday life and access to healthcare. Nordic Journal of Migration Research 8(3): 167-174.

Betts A (2011) Global Migration Governance. Oxford: Oxford University Press.

Betts A (2013) The migration industry in global migration governance. In: Gammeltoft-Hansen T and Nyberg Sørensen N (eds) The Migration Industry and the Commercialization of International Migration. London: Routledge, pp. 45-63.

Brenner N (1999) Globalisation as reterritorialisation: The re-scaling of urban governance in the European Union. Urban Studies 36(3): 431-451.

Carrera S (2007) The EU Border Management Strategy: FRONTEX and the Challenges of Irregular Immigration in the Canary Islands. Brussels: Centre for European Policy Studies.

Coe N M, Johns J and Ward K (2007) Mapping the globalization of the temporary staffing industry. The Professional Geographer 59(4): 503-520.

Cohen S (2002) The local state of immigration controls. Critical Social Policy 22(3): 518-543.

Cranston S (2014) Reflections on doing the expat show: Performing the global mobility industry. Environment and Planning A: Economy and Space 46(5): 1124-1138.

Cwerner S B (2004) Faster, faster and faster: The time politics of asylum in the UK. Time \& Society 13(1): 71-88.

Darling J (2016) Privatising asylum: Neoliberalisation, depoliticisation and the governance of forced migration. Transactions of the Institute of British Geographers 41(3): 230-243. 
de Lange T (2011) The privatization of control over labour migration in The Netherlands: In whose interest? European Journal of Migration and Law 13(2): 185-200.

Doty R L and Wheatley E S (2013) Private detention and the immigration industrial complex. International Political Sociology 7(4): 426-443.

Emerson K, Nabatchi T and Balogh S (2012) An integrative framework for collaborative governance. Journal of Public Administration Research and Theory 22(1): 1-29.

Enright B and Pemberton S (2016) Strategies and tactics for local market making in the temporary staffing industry. Geoforum 74: 9-18.

Ewers M C (2007) Migrants, markets and multinationals: Competition among world cities for the highly skilled. GeoJournal 68(2-3): 119-130.

Faulconbridge J R, Beaverstock J V, Hall S, et al. (2009) The 'war for talent': The gatekeeper role of executive search firms in elite labour markets. Geoforum 40(5): 800-808.

Flynn M and Cannon C J (2009) The privatization of immigration detention: towards a global view. $A$ global detention project working paper. Available at: www.ssrn.com/abstract $=2344196$, accessed on 25 August 2021)

Freeman G P (1995) Modes of immigration politics in liberal democratic states. International Migration Review 29(4): 881-902.

Goh C, Wee K and Yeoh BSA (2017) Migration governance and the migration industry in Asia: Moving domestic workers from Indonesia to Singapore. International Relations of the Asia-Pacific 17(3): 401-433.

Guiraudon V and Lahav G (2000) A reappraisal of the state sovereignty debate: The case of migration control. Comparative Political Studies 33(2): 163-195.

Hedberg C and Olofsson I (forthcoming) Negotiating the wild west: Variegated neoliberalisation of the Swedish labour migration regime and the wild berry migration industry. Environment and Planning A: Economy and Space.

Hiemstra N and Conlon D (2017) Beyond privatization: Bureaucratization and the spatialities of immigration detention expansion. Territory, Politics, Governance 5(3): 252-268.

Infantino F (2016) Outsourcing Border Control: Politics and Practice of Contracted Visa Policy in Morocco. New York: Palgrave Macmillan.

Jenkins M (2014) On the effects and implications of UK border agency involvement in higher education. The Geographical Journal 180(3): 265-270.

Jessop B (1994) Post-fordism and the state. In: Amin A (ed.) Post-Fordism: A Reader. Oxford: Blackwell, pp. 251-279.

Kern A and Müller-Böker U (2015) The middle space of migration: A case study on brokerage and recruitment agencies in Nepal. Geoforum 65: 158-169.

Khan M (2019) Contested ground: Network governance in Australia's migration industry. International Migration 57(3): 295-309.

Klijn E-H (1996) Analysing and managing policy processes in complex networks: A theoretical examination of the concept policy networks and its problems. Administration \& Society 28(1): 90-119.

Knox A (2018) Regulatory avoidance in the temporary work agency industry: Evidence from Australia. The Economic and Labour Relations Review 29(2): 190-206.

Koh S Y and Wissink B (2018) Enabling, structuring and creating elite transnational lifestyles: Intermediaries of the super-rich and the elite mobilities industry. Journal of Ethnic and Migration Studies 44(4): 592-609.

Koslowski R (2014) Selective migration policy models and changing realities of implementation. International Migration 52(3): 26-39.

Kunz R, Lavenex S and Panizzon M (2011) Multilayered Migration Governance: The Promise of Partnership. Abingdon: Routledge.

Lahav G (1998) Immigration and the state: The devolution and privatisation of immigration control in the EU. Journal of Ethnic and Migration Studies 24(4): 675-694.

Lavenex S (2006) Shifting up and out: The foreign policy of European immigration control. West European Politics 29(2): 329-350. 
Leitner H (1997) Reconfiguring the spatiality of power: The construction of a supranational migration framework for the European Union. Political Geography 16(2): 123-143.

Martin LL (2012) 'Catch and remove': Detention, deterrence, and discipline in US noncitizen family detention practice. Geopolitics 17(2): 312-334.

Menz G (2013) The neoliberalized state and the growth of the migration industry. In: GammeltoftHansen T and Nyberg Sørensen N (eds) The Migration Industry and the Commercialization of International Migration. London: Routledge, pp. 108-127.

Millar J and Salt J (2007) In whose interests? IT migration in an interconnected world economy. Population, Space and Place 13(1): 41-58.

Ministry of Justice (2007) Regleringsbrev för budgetåret 2008 avseende Migrationsverket. Available at: www.esv.se/statsliggaren/regleringsbrev/?rbid = 10512, accessed on 25 August 2021.

Ministry of Justice (2009) Regleringsbrev för budgetåret 2010 avseende Migrationsverket. Available at: www.esv.se/statsliggaren/regleringsbrev/?rbid = 11992, accessed on 25 August 2021.

Ministry of Justice (2016) Regleringsbrev för budgetåret 2017 avseende Migrationsverket, Available at: www.esv.se/statsliggaren/regleringsbrev/?rbid $=18175$, accessed on 25 August 2021.

Nathan M and Vandore E (2014) Here be startups: Exploring London's 'tech city' digital cluster. Environment and Planning A: Economy and Space 46(10): 2283-2299.

Nowell LS, Norris JM, White DE, et al. (2017) Thematic analysis: Striving to meet the trustworthiness criteria. International Journal of Qualitative Methods 16(1): 160940691773384.

OECD (2011) Recruiting Immigrant Workers: Sweden 2011. Paris: OECD Publishing.

Panizzon M and van Riemsdijk M (2019) Migration governance in an era of large movements: A multi-level approach. Journal of Ethnic and Migration Studies 45(8): 1225-1241.

Parliamentary Ombudsman (2014) Kritik mot Migrationsverket för långa handläggningstider i tillståndsärenden och för att regeringsformens krav inte har beaktats när webbsökningar prioriterats. Dnr 5497-2013.

Rhodes R A W (1994) The hollowing out of the state: The changing nature of the public service in Britain. The Political Quarterly 65(2): 138-151.

Sánchez-Barrueco M-L (2018) Business as usual? Mapping outsourcing practices in Schengen visa processing. Journal of Ethnic and Migration Studies 44(3): 382-400.

Scholten S (2015) The Privatisation of Immigration Control through Carrier Sanctions. Leiden: Brill.

Schweitzer R (2017) The Micro-Management of Migrant Irregularity and its Control. Brighton: University of Sussex.

Somerville W and Goodman S W (2010) The role of networks in the development of UK migration policy. Political Studies 58(5): 951-970.

Statham P and Geddes A (2006) Elites and the 'organised public': Who drives British immigration politics and in which direction? West European Politics 29(2): 248-269.

Swedish Migration Agency (2011) Certifiering av företag aktuella i arbetstillståndsärenden, VCI 6/ 2011.

Swedish Migration Agency (2012) Certifiering av företag aktuella i arbetstillståndsärenden VCI 3/ 2012.

Swedish Migration Agency (2018a) Chefen för digitaliserings- och utvecklingsavdelningens instruktion om standard för uppföljning av certifieringssystemet och upphävande av certifiering, I-27/2018.

Swedish Migration Agency (2018b) Handbok i migrationsärenden, version 2018-10-25.

Swedish Migration Agency (2019) Arsredovisning 2018. Norrköping: Swedish Migration Agency.

Swedish National Audit Office (2016) Ett välfungerande system för arbetskraftsinvandring? RIR 2016:32.

van Riemsdijk M (2012) (Re)scaling governance of skilled migration in Europe: Divergence, harmonisation, and contestation. Population, Space and Place 18(3): 344-358.

Xiang B (2007) Global 'Body Shopping': An Indian Labor System in the Information Technology Industry. Princeton: Princeton University Press.

Xiang B (2012) Predatory princes and princely peddlers: The state and international labour migration intermediaries in China. Pacific Affairs 85(1): 47-68. 
Yeoh B S A, Chee H L and Baey G (2017) Managing risk, making a match: Brokers and the management of mobility in international marriage. Mobilities 12(2): 227-242.

Yuval-Davis N, Wemyss G and Cassidy K (2018) Everyday bordering, belonging and the reorientation of British immigration legislation. Sociology 52(2): 228-244.

Zhang Q and Axelsson L (2021) Channelling through bureaucracy: How migration intermediaries and state actors (re)shape Chinese migration to the Swedish restaurant industry. Geoforum 123: 14-22.

Zolberg A (2003) The archeology of "remote control. In: Farhmeir A, Faron O and Weil P (eds) Migration Control in the North Atlantic World. New York: Berghahn Books, pp. 195-222.

Linn Axelsson is Research Fellow in Human Geography at Stockholm University. Her research interests include critical border studies, migration governance, international labour migration and precarious work. She currently leads a research project on the growing involvement of non-state actors in the regulation of international labour migration. Her work has appeared in Political Geography, Geoforum and The Journal of Ethnic and Migration Studies, among other venues.

Nils Pettersson is Research Assistant at the Department of Human Geography, Stockholm University. His research interests include environmental and migration governance, with a particular focus on public-private relationships. 